\title{
BETRAYING AND DELIVERING: FILMING DISGRACE
}

Ian Glenn

University of Cape Town

\begin{abstract}
While much criticism of film adaptation has focused on issues of fidelity to original literary texts, this article argues that the film version of J. M. Coetzee's Disgrace 'betrays' the original novel through faithfully revealing the tensions and contradictions of the original. The article also examines the ways in which the film attempted to give a more positive portrayal of South Africa through an emphasis on Lucy rather than her father, but points to ways in which the shock of the central violent crime in the film exceeds that in the novel.
\end{abstract}

\section{Introduction}

Tradurre, tradire-to translate is to betray, the Italian proverb tells us. But the root of both tradurre (to translate) and of tradire (to betray) is, etymology shows, in the Latin tradere, to hand over. In English, the word betray means both to behave treasonously, but also to reveal that which would otherwise remain hidden ('the shaking of his hand betrayed how the news had shocked him'). The 2008 film of J. M. Coetzee's 1999 novel Disgrace, directed by Steve Jacobs and

\begin{tabular}{|l|l|l|l|l|}
\hline Ilha do Desterro & Florianópolis & n 61 & p. 269- 282 & jul/dez 2011 \\
\hline
\end{tabular}


starring John Malkovich, shows that faithful adaptation can highlight problems in a way wilder adaptations never could. (Coetzee; Jacobs) The film of Disgrace shows that accurate adaptation, in this case the screenplay by Anna Maria Monticelli, betrayed, not in the sense of distorting, but of revealing, bringing to the light, some of the problems and tensions of the original.

Before seeing the film Disgrace, I had, in writing about the not yet made film, speculated about the likely effects of casting and the political reading of the film. I hypothesised that the casting of Malkovich, the only internationally renowned actor, as Lurie would increase the separation between Lurie and the other characters, reinforcing the novel's privileging of the central consciousness of Lurie, (Glenn "Sex") and that the film would re-inforce a sense of liberal Afro-pessimism (Glenn "Gone"). The director's decision to stress the daughter's role and Jessica Haines's strong performance as Lurie's daughter Lucy make me less certain about the former claim while the very limited distribution internationally of the film makes it difficult to judge its social impact. Even in South Africa, it had a short run in a very few cinemas.

What I did not expect was that the film would echo and reveal the dramatic shortcomings of the novel. My argument will thus be that the film did not betray some ideal version of the novel, but came up against the limitations, social and imaginative, of the novel itself. And this, surely, is what we have to expect would happen when the author seems to have kept such close control over the script.

My tribute to the filmmakers, back-handed though it may seem, is that they worked, both in the script and the film itself, to keep the film as faithful to the novel as possible. In the months and years they spent working with clever thoughtful actors and a range of experts, they surely explored the possibilities of the film as thoroughly and 
dialectically as any critic ever has. Their achievement, in other words, is to have extracted what could be extracted from the story, or what could be extracted while remaining faithful to the intention of the author.

In this analysis, I discuss six crucial areas: the relationship between Lurie and Melanie (played by Antoinette Engel) the attempt to understand what motivates Lurie; the portrayal of black on white violence; the role of Petrus (Eriq Ebouaney); the portrayal of Lucy; and the role of landscape.

\section{Lurie and Melanie}

The relationship-one can scarcely call it a love affair-between Lurie and Melanie changes in some ways from novel to film. The directors removed any sense of Melanie's agency, omitting plot elements like her turning up at Lurie's flat, or any sense of her slyness, or pleasure at having Lurie's attention, or the clear, if coded reference to her sensuality, shown in her orgasm(s) and active sexual participation: "She is quick and greedy for experience......she hooks a leg behind his buttock to draw him in closer..." (Coetzee, 29). The contrast with Lurie's sexually frustrating encounter with the departmental secretary seems deliberate in the novel and helps explain his fascination with the young student but in the film Melanie seems to have been chosen and cast precisely to highlight a sense of vulnerability and exploitability.

In the film, the first sexual encounter between them is reduced to Lurie's achieving sexual release through the crudest kind of selfabsorbed action, where Melanie might as well have been a blow-up doll. They remain more or less full clothed, her panties around her ankles, his coat still on. Her physical reaction, lying like a victim with her hands above her head, points to her essential passivity. While this hasty intensity tracks the description in the novel closely, it misses 
out Lurie's sense of blissful union.

Had the film shown Melanie as willing or sexually pleasured partner, not just in Lurie's consciousness, but physically-crying out in pleasure or wrapping a leg around Lurie, say-then Melanie's later behaviour would have seemed more hypocritical, Lurie less culpable. And here the film seemed to want moral melodrama rather than complexity. The closest the director and script-writer can get to showing Melanie as agent is by telescoping what are two sexual encounters in the novel into one: Lurie's almost forced entry to her apartment and their final, apparently reciprocated, love-making in his flat. This now becomes one encounter where he enters the flat but she comes naked to the bed-a sign that the film more or less threw its hands up about the novel's ambivalence and ambiguity and decided to give both elements. The problem with the nudity scene is that Melanie appears as self-sacrificial sexual offering, rather than as participant or sexual agent and certainly not as woman taking or even involuntarily getting pleasure in the act.

But, though one can argue that the film flattens the complexity of the relationship and turns Melanie into startled victim rather than complex collaborator, the novel too ignores Melanie as sexual being, or the erotics of inter-generational seduction, or what made her do it. The novel, as basis for the script gives very little imaginative grist for a film that would have explored her ambivalence or explained what made her an erotic object for Lurie or even explained what made Lurie successful in his seduction. In ignoring these issues, the film, like the novel, leaves us with plot elements like Lurie's devious search for her address or the cheated mark for the test, as the key issues of the relationship. There is no moment of intimacy, or pleasure, or connivance between them to balance against the issues of unethical professional behaviour or gender and even racial exploitation.

The second area where the film echoes the novel but, in so 
doing, throws doubt onto the original, lies in the equivalences or parallels between the inter-racial sexual transgressions. The film, like the novel, produces a plot with a suggestion that the actions against Lucy are, to some extent, a retribution on Lurie for his sexual exploitation of Melanie. Lucy suggests the links between David and the rapists by reducing them all to 'men' desiring to possess women, and the plot parallels Lurie returning to watch Melanie in the theatre with Pollux (Buyami Duma), the boy-rapist returning to spy on Lucy in the shower. The most effective cinematic metaphor probably occurs when Melanie's boyfriend Ryan (Charles Tertiens) flicks his lit cigarette at Lurie when he returns to watch Melanie in the theatre, driving him off and ominously recalling the young men setting him alight.

Most viewers of the film, however, are surely likely to reach the common-sense conclusion that there is a vast and significant moral and legal difference between seduction of a girl who won't or can't say no, and violent gang-rape and attempted murder. Literature, in other words, can leave things more subtle, more morally murky, whereas film brings the actions and contrasts and parallels into stark relief. Here again, the link between film and novel is not that the film betrayed the novel but that it mirrored its uncertainty, if not incoherence, faithfully.

\section{Lurie and 'mad heart' disease}

The film publicity made much of the 'mad heart' reference as a way, a shorthand perhaps, of at once explaining, magnifying, yet pardoning Lurie. The original reference is to Lucifer in Byron's Lara, and to the exchange with Ryan in his class (33). But the film publicity clearly suggests that the reference extends to Lurie.

In its simplest form, this seems to equal a justification of Lurie's 
sexual instinct as profound, intrinsic, source of instinctual truth. This is a repeated motif in the novel-found in the reference to Blake and the injunction against nursing 'unacted desires' and the claim that his education has come from women close to him (69-70), in the claim to the 'rights of desire' and the story of the golden retriever dog punished for following its instincts (89-90) and in Lurie's sudden 'hypnagogic' memory of all the women with whom he has ever been intimate and his sense of having been 'enriched' by them (191-92). This is Lurie as a D H Lawrence protagonist, with a powerful sense that the crucial encounters of our lives are the sexual as the most powerful, most sensual, however evanescent. In Lurie's linking of the memory of the German tourist with Langland's 'fair field full of folk' from Piers Plowman, probably the earliest extant quote in English literature, Coetzee even suggests that literature itself has, from its origins, a strongly sensual and sexual drive in spite of its ostensible concerns of moral geography, and this is repeated in references to other literary works like Yeats's 'Sailing to Byzantium'.

The novel, like the film, offers these claims to counter those, from Lucy and indeed from the action itself. If Lurie is able to justify his 'rights of desire' or argue against nursing unacted desire, then by what measure is he to condemn the rapists? Yet neither novel nor film can make conscious the parallels or differences and thus Lurie, for all his articulate fluencies, can not explore this crux. The moral life, or life of moral reflection, seems essentially blind, out of his own control, in the hands of God, as Isaacs says, or of more profound psychic drives, or late-flowering testosterone.

The film reduces Lurie's moments of discovery of the limits of his own self-knowledge, or of his quest for grace, or his acceptance of his disgrace, into the simplest gestures of physical abasement and the bowing of his head: when he bends his head over the 
steering wheel of the car and cries, or when, after hearing that Lucy is pregnant and plans to keep the child, he goes outside the house to put his head against the house, or when he bows his head to the floor in the Isaacs house as sign of penitence. While these seem quite effective as primary signs of his changed mental or psychic state, they are not, in the film or the novel, linked to the puzzling issues of what Isaacs' statement about God is meant to portend or in fact to any sense of the workings of Lurie's conscience or consciousness. In the film, the scene with Isaacs (played by David Dennis), potentially one of the most powerful moments of moral confrontation in the film, was distorted almost literally by a framing of Isaacs with his head right at the top of the shot, seeming to signify a larger than human role as angel or avenging figure, but, as in the novel, where Lurie reduces Isaacs' statements to 'tricks', it is hard to know what was intended.

\section{Kill the Wizards, kill the farmers}

Where the film, very briefly, seems to escape the original intention or vision of the novel, it does so because of ways in which social reality bursts out, perhaps unwittingly, in ways which heighten a sense of social pessimism about a white future in Africa and thus Afro-pessimism more generally.

The central, pivotal incident in the film, as in the novel, is the violent attack on Lucy and Lurie. In the novel, the actual incident takes up five or six pages out of two hundred and nineteen, or between two and three percent of the text. In the film, the scene takes about six minutes out of ninety, which gives it about twice as much weight and space proportionately. In its graphic detail, as in the shooting of the dogs, and the attempt to set David alight, it weighs correspondingly more heavily. 
Then there is a crucial change, which for South African viewers in particular, must weigh heavily on the interpretation. In the original, Lurie, locked up in the toilet, looks out of the window:

A car door slams. He recognises the sound: his car. The man reappears empty-handed. For a moment the two of them look straight into each other's eyes. 'Hai!" says the man, and smiles grimly, and calls out some words. There is a burst of laughter. A moment later the boy joins him, and they stand beneath the window, inspecting their prisoner, discussing his fate.

He speaks Italian, he speaks French, but Italian and French will not save him here in darkest Africa. He is helpless, an Aunt Sally, a figure from a cartoon, a missionary in cassock and topi waiting with clasped hands and upcast eyes while the savages jaw away in their own lingo preparatory to plunging him into their boiling cauldron. Mission work: what has it left behind, that huge enterprise of upliftment? Nothing that he can see. (95)

In the film, none of Lurie's sardonically pessimistic thoughts remain. Instead, what we have is far more threatening. When he looks out of the window he sees one of the young men who now has the rifle which Lurie immediately sees as a threat, cowering down to the floor in response. The boys have changed from the servile suppliants asking for a favour and now are cocky and in control.

The men return, as in the novel, set him alight and leave him. Lurie manages to douse the flames with the water in the toilet. As the men leave, he hears their final words outside the window. The last intelligible word is "Bulala"-the Zulu and Xhosa word for kill, to which the response is laughter. Given that the men have just killed the dogs and tried to murder Lurie, in a scene with strong echoes of township necklacings, the note of gleeful murder is distressingly sinister. The word wrestles the film from Lurie's anglophile agonising about the failure of missionary upliftment, into a different, older, 
powerful Afrikaner model of suspicion. We are, here again, back at Dingane's kraal where the perfidious Zulus lure Piet Retief and his men in under the pretext of signing a treaty, persuade them to hand over their weapons, and then at a crucial moment, call out "Bulalani abathakathi..." (a Zulu phrase meaning 'Kill the Wizards').

As Piet Retief had disarmed, so Lucy, gulled by the story of the man's pregnant sister and his need to use the phone, has kenneled the dogs and not fetched her rifle. In consequence, the men rape her, try to kill Lurie (something the film makes clearer than the novel did), and then use the rifle to murder the dogs.

Whose decision was it to take that word, which reverberates from Dingaan to the controversial revolutionary slogans of 'One settler, one bullet', or 'Kill the farmer, kill the boer' or ANC Youth League President Julius Malema's chilling statement that he was ready to kill for Zuma, and leave it as the defining statement of intent from the men outside the window? It is not blatantly there in the novel, though there certainly is the suggestion ('he can burn, he can die'), but there is a later moment in the film that re-inforces it. When Lurie finds Pollux spying on Lucy and drives him off, the boy yells, in the novel, "I will kill you" and then, as he tramples the planted vegetables, sign of pastoral progression from a hunter society, "We will kill you all". In the novel these threats may seem like empty bravado but in the film, accompanying the trampling of the vegetable bed, they seem less like childish threat, more like a deep desire and teleology.

The film, in other words, wittingly or not, leaves us with the reduction of young black masculinity to the killing instinct. It insists on the bleakest reading possible of the failure of the project of upliftment or, indeed, of reconciliation. In this reading, the film turns Coetzee's Afro-pessimism from the European clichés of missionaries 
in cooking pots into something far more indigenous: an Afrikaner suspicion of black anti-colonial and anti-white rage and vengeance.

\section{The role of Petrus}

The novel leaves the role or culpability of Petrus in the rape open to interpretation. Lurie is suspicious of his absence, particularly when it turns out that one of the rapists is his brother-in-law. The film heightens the issue of Petrus's benefiting from the rape by juxtaposing the scene in which Lurie's car and their possessions are robbed with the next scene in which we see Petrus where he reappears in an unexplained burst of prosperity, offloading building materials from a truck. This editing juxtaposition suggests Petrus's rise as somehow linked to, consquent on, the act of violence and robbery. Lurie watches Petrus suspiciously after the rape and the film does nothing to discourage this suspicion, particularly in insisting on Petrus' defence of the boy as one of 'his people'.

As I have argued in analysing the novel, against David Attwell's suggestion that Petrus is a paysan rather than a racial figure, (Attwell) Petrus becomes a fairly sinister metaphor of Black Economic Empowerment, in that his offer of protection seems linked to the threat of violence against whites and the implicit promise of protection through the creation of a black barrier class between whites and poor blacks (Glenn "Gone"). While Lucy sees herself being able to live under Petrus's protection if she accepts his offer of marriage, the novel and film as a whole take a more pessimistic line. The scene that follows Lucy's acceptance that she will be humiliated and have to live like a dog is the Pollux Peeping Tom scene which suggests Petrus's failure to control the sexuality of the young men. To agree to live like a dog does not guarantee protection and the way Petrus treats the sheep about to be slaughtered casts a grim shadow 
over the notion. Sociologically speaking, a more realistic gauge of inter-generational behaviour in the Eastern Cape, as shown by Jonny Steinberg's description in Three Letter Plague, is that the older generations and traditions have very little power over the sexual or criminal behaviour or drives of the young (Steinberg).

\section{The unreadability of Lucy}

What are we to make of Lucy's refusal to prosecute the rape charge, or to have an abortion? Is she suffering from post traumatic stress disorder or making a profound social statement about the need for sacrifice by white women to compensate for the sins of the past? Lucy's attack on Lurie about men liking taking women by force suggests her role as typical nineteenth century white heroine suffering for the sexual sins of white men seduced by young women of colour. One of the most forceful tropes of white women arguing against miscegenation was that the failure of white men to curb their sexual predatoriness would lead to retaliation from black men, so that the film repeats, like the novel, a strong and influential element of white racial feminist discourse (Glenn "Legislating").

While Jessica Haines's performance is assured, the film does not resolve the problems set by the novel. In some ways, it seems as though the Australian director's point of view was that Lucy's decision to stay suggests a triumph of will, an optimistic take on the South African situation and the future. My sense from talking to South African female viewers, however, is that for them Lucy's situation felt intolerable, claustrophobic, terrifying. Rather than producing an optimistic view of the future, the stress on Lucy may have done just the oppositeand this seems to have been the dominant response, in part leading to the film's lack of commercial viability in South Africa and perhaps elsewhere. At moments then, it felt almost as though this was a South 
African version of Bunuel's Viridiana, a parable of the folly of liberal good intentions, of what happens to benefactors, but the film, through stressing Lurie's unconditional support of Lucy's decision-something not in the novel-does not allow this reading to develop.

\section{The role of landscape and the ending}

The move of the action from the Eastern Cape in the novel to the far more picturesque Cederberg in the film no doubt betrays the original in terms of the feel of the landscape, but in key ways the physical irreality of the film mirrors that of the novel. Where, one wonders, do the party-goers in the film come from, given the film's insistence on the splendid isolation of the farm? There is no sense, in novel or film, of who owned or worked the land before Lucy and Petrus, of who the previous farm workers were or what has happened to them-considerations that are not only humanly important but legally so in terms of land claims and how locals see places. So, where do the party-goers in the novel come from, given the very uncertain sense of who the neighbours are and what the land claims involve and for whom?

The film's ending replaces the ending of the novel, in which Lurie gives up the three-legged dog that is devoted to him, for euthanasia, presumably another sign of acceptance and renunciation. The film now ends with a long shot of Lucy's house which then tracks back until the audience sees not only Lucy's house as the central element but also Petrus's house next to and the small additional building in front of it and then finally fades to blue, probably showing the passage of time. The intention of this scenic finale is presumably to show not only the beauty of the Cederberg, but also a state of co-existence in which Lucy's house is now complemented by Petrus's house, and in which the tension Lurie felt at seeing the building going up next door 
is now alleviated, taken into a larger sweep of history, seen sub specie aeternitatis.

This ending, with its invocation of balance and resolution, seems foreign to the novel's much bleaker sense of relentless invasion of shanty towns into Cape Town, or the film's own build-up of Lurie's claustrophobia and sense of invasion by the building next door. Yet, though this model of distant integration and resolution seems imposed by a wish to end the film with a sop of optimism, or at least perspective, the problem is that the original novel leaves, bleakly, no model or vision of a social future, no sense of whether Lucy's child may prove to be a bridge between houses and cultures, or a further cause of separation and anger, of whether Lurie goes or remains, of whether Petrus can have any control over the murderous young rapists. In this scene, the film's end imposes a social vision, from the filmmakers leaving the country behind them, one is tempted to say, which arises from the indeterminacy of the novel.

\section{Conclusion}

What I have argued is that the film Disgrace represents, fairly faithfully, the emotional and social vision of Coetzee's novel. Coetzee played a role in censoring (in the sense of allowing) the script and in general seems to have been content with script and actors. My argument has thus been that we have to accept the logic of his position and read some, if not all, of the weaknesses of the film, not as betrayals of the novel in the sense of infidelities, but of betrayal as revelations.

\section{References}

Attwell, D. "Race In Disgrace." Interventions: The International Journal of Postcolonial Studies 4.3 (2002): 331-341. 
282 Ian Glenn, Betraying and delivering: filming Disgrace

Coetzee, J. M. Disgrace. London: Secker \& Warburg, 1999.

Glenn, I. "Legislating women.” Journal of Literary Studies 12.112 .2 (1996): 145-70.

Glenn, I. "Sex, Race and Casting in South African Cinema". Marginal Lives \& Painful Pasts: South African Cinema After Apartheid. Ed. M. Botha. (Cape Town: Genugtig!, 2007): 343-357.

Glenn, I. “Gone for good." English in Africa 36. 2 (2009): 79-98.

Jacobs, S. Disgrace. 2008.

Steinberg, J. Three letter plague : a young man's journey through a great epidemic. London: Vintage, 2009.

[Received in 28/07/2011. Approved in 22/11/2011] 